\title{
A tale of two tables
}

M. Pilar Gil and Eli Zysman-Colman look back at the history of two periodic tables that date from the late nineteenth century.

A periodic table (Fig. 1) discovered in the School of Chemistry at the University of St Andrews in Scotland in 2014 has recently been dated as the oldest known published classroom example ${ }^{1}$. The first mention of this table uncovered so far appears in a collection ${ }^{2}$ on the history of chemistry written by the scholar and bibliographer of chemistry, Henry Carrington Bolton. Published in 1893, this treatise includes a total number of 12,031 works in 25 different languages and represents an exhaustive list of chemistry-related publications from the previous 500 years ${ }^{3}$. It should be noted that a painted periodic table (and hence not a commercial product) linked to Mendeleev — and ostensibly dating back to 1876 - exists in the chemistry building of St Petersburg State University, Russia ${ }^{4}$.

On page 82 of Bolton's work, there is an entry for a periodic table wall chart that bears the same title and the same place of publication as the table found in St Andrews: 'Wandtafel der periodischen Gesetzmassigkeit der Elemente nach Mendelejeff. Wien, 1885.' A similar entry appears in another compendium ${ }^{5}$, Carl Georg and Leopold Ost's 1889 Sclagwort-Katalog, which lists books and maps published in Germany from 1883-1887. The citation reads: 'Wandtafel der periodischen Gesetzmässigkeit d. Elemente nach Mendelejeff. Wien 85. Helf's Sort. 2 -'. To the best of our knowledge, these are the only two citations corresponding to a periodic table that appear in both compendiums, suggesting that these are indeed referring to the first ever published periodic table wallcharts.

It is thought that one copy from this set of tables — which were published in 1885 in Vienna was sold ${ }^{6}$ by C. Gerhardt in Bonn, Germany, in October 1888. According to financial records of the University of St Andrews (kept within the institutional archive of the university ${ }^{7}$ ) this periodic table arrived later the same year in St Andrews, via Rotterdam. This purchase represents an early example of long-distance commerce that enabled scientists to acquire goods and publications in an international market. 
International trade does not, however, seem to explain the provenance of another early classroom periodic table that today forms part of a private collection. This tableau, printed in French, was found in the city of Koblenz, Germany, in 1980. It was during the taking of an inventory intended to clear out old equipment in the chemistry division of the Max-von-Laue Gymnasium in Koblenz, when a rolled-up chart was found at the back of an old cabinet. It turned out to be an early example of a classroom periodic table, possibly one of the first ever published in French (Fig. 2).

In sharp contrast with the St Andrews table, which has additions of chalk marks and signs of an eventful life in the classrooms or laboratories, the Koblenz periodic table did not exhibit any signs of habitual use - there was no evidence that it had ever been hung up - although the paper was yellowed and brittle. Moreover, the lack of any reference to a printer, lithographer or publisher left little possibility of tracing its provenance or offering any definitive proof of the year in which it was created. As was the case with the table found in St Andrews, however, an inspection of the elements present in - and absent from - the table allowed for the approximate date of its publication to be established. The presence of germanium, which was discovered in 1886 and is missing in the St Andrews table, as well as the absence of the whole group of noble gases (argon, the first one discovered, was announced in 1894) suggests that the table was published in either the late 1880 s or the early 1890 s.

Why was a French periodic table that was likely published around the end of the 19th century, found in a city in Germany in the second half of the 20th century? Unlike the St Andrews table, the answer almost certainly lies in the changing context of world politics, with war and occupation also playing a part. The institution and the city where the table was found are a testimony to turbulent times in the past. Koblenz, a city named after the confluence of two rivers, the Rhine and the Moselle, has been a coveted and disputed area in its more than 2,000 years of history ${ }^{8}$. During the 20th century, as a consequence of peace settlements and treaties after the two world wars, the city and the province were occupied by different foreign armies. In 1918, American troops occupied the city and it was later transferred to the French in 1923. The French occupation lasted until 1929. The aftermath of World War II saw a new change of powers in the city when, after being occupied again by the Americans, the sovereignty of Koblenz fell once more to France as a result of the Treaty of Versailles in 1945. This period of French occupation lasted until 1957, when the city reverted back to German control ${ }^{9}$. 
During the second French occupation, the lives of the troops and their families were organized around a new self-contained town where a cinema and a school for the children of the occupying army constituted the focal points ${ }^{10}$. The school, the Collège Marceau, was first established in an old building - surrounded by ruins of air attacks - that had served as a school for French pupils in the early part of the 20th century. The Collège Marceau subsequently moved to a new building in 1953 and hosted French children until 1957, at which point the Max-von-Laue Gymnasium ${ }^{11}$ was established on the site. Twenty-three years later, the old 'Table de Mendeléeff' (Fig. 2) was found in the chemistry department of this school. The history of the building, particularly its use as a school for French pupils, gives a plausible explanation to why this particular periodic table was found there. The provenance of the table is undoubtedly entangled with the history of the directors, teachers and pupils of the Collège Marceau.

The city of Koblenz suffered heavy bombing and ground battles during World War II, resulting in a staggering $84 \%$ drop in the population because of either death or evacuation; more than $67 \%$ of its dwellings were destroyed between 1939 and $1945^{12}$. It is, therefore, somewhat remarkable that the Koblenz periodic table survived this terrible episode - so not only is this particular wallchart relevant from the standpoint of chemical history, but is significant because of its endurance through a period of major turmoil in Europe's past.

Comparing the tables from St Andrews and Koblenz, one appreciates that there are some similarities, yet some notable differences. The St Andrews table contains 65 elements, with spaces left for elements that were expected and predicted but were unknown at the time. One important gap is germanium, described by Mendeleev as 'ekasilicon', which was discovered in 1886, the year following the publication of this table. The entry for 'Di' corresponds to the supposed element 'didymium' that, in 1885, was separated into two elements, neodymium and praseodymium. The display of the elements in the table, as well as their atomic weights, is very similar to Mendeleev's second table published in 1871 in a review paper that, in its German version, bears the same title as the heading on the wallchart ${ }^{13}$. Although the title of the Koblenz table also mentions Mendeleev, the table has particularities that contribute to its uniqueness. These include its heading, the distribution of the elements, as well as the inclusion — or omission - of some of them. 
The subtitle of the Koblenz table reads 'Groupement périodique et naturel des éléments' and gives a short explanation of the method used to layout the elements on the chart: the elements are distributed vertically according to their atomic weight and horizontally based on their related properties. This arrangement of the elements - similar to the original classification announced ${ }^{14}$ by Mendeleev in 1869 - was not the representation typically used following the publication of Mendeleev's article in 1871 in which the elements with similar chemical and physical properties were distributed in columns with atomic weight increasing gradually across the horizontal periods.

There are 66 elements listed in the Koblenz table (one more than the St Andrews table) and, as previously noted, it includes entries for germanium and didymium but the noble gases are absent. Interestingly, some elements appear in a different order than expected. This is the case for mercury $(\mathrm{Hg})$, which can be found in the first group with the alkali metals; at the time this site was usually occupied by gold ( $\mathrm{Au}$ ) and $\mathrm{Hg}$ was typically situated in the second group (as can be seen in the St Andrews table in Fig. 1). Interestingly, mercury was placed in the first group in another table found in an encyclopaedic dictionary published ${ }^{18}$ in French in Paris in 1883. Also, in both of these French tables the element beryllium is called glucinium (GI), a name originating from the sweet taste of beryllium salts ${ }^{19}$ and commonly used in the French scientific literature at the time. IUPAC weighed in on the official name (beryllium) for the fourth heaviest element in 1949.

In the Koblenz table there are also some notable absences. Tungsten (W), for instance, is missing although it was isolated in 1783 and was present in all other representations of the periodic table at that time. In its place we find thulium (Tm), an element discovered in 1879 and one that is usually absent in early periodic tables. The presence of thulium disturbs the gradual increment in the atomic weights, giving the impression that its inclusion could be due to an error, a confusion with the chemical symbol 'Tu' that was sometimes used for tungsten (instead of the symbol 'W' derived from wolfram, the name originally recommended by IUPAC) ${ }^{20}$. An example of the use of Tu as a symbol for both Tm and W can be found in O. D. Khvolson's Traité de Physique ${ }^{21}$.

Unlike the St Andrews table, for which the research to find its year of publication led to documents in the university's archives that helped to trace its provenance, the origins and history of the Koblenz table remain a mystery. The table does not seem to be present in French or Belgian 
trade catalogues and there are no entries for the table in the national archives of French-speaking countries, nor in any known library catalogue. Two periodic tables, most likely published only a few years apart and with different origins and eventful pasts, are a testimony to the evolving understanding of chemistry and the building blocks that make up the universe we inhabit. Forgotten for many decades and found by happenstance during clean outs, their stories will hopefully catalyse renewed interest in chemistry for today's young generations of students.

\section{Pilar Gil}

University of St Andrews, Library Annexe, North Haugh, St Andrews, Fife, KY16 9WH, UK. e-mail: mpg6@st-andrews.ac.uk

\section{Eli Zysman-Colman}

Organic Semiconductor Centre, EaStCHEM School of Chemistry, University of St Andrews, Purdie Building, North Haugh, St Andrews, Fife, KY16 9ST, UK.

e-mail: eli.zysman-colman@st-andrews.ac.uk

Twitter: @ezc_group

\section{References}

1. O'Hagan, D., Gil, M. P. \& Aitken, A. Chemistry World (February 2019) $<$ https://www.chemistryworld.com/opinion/is-this-the-worlds-oldest-classroom-periodictable/3009960.article>

2. Bolton, H. C. A select bibliography of chemistry, 1492-1892 (Smithsonian Institution, 1893).

3. Browne, C. A. J. Chem. Educ. 17, 457-461 (1940).

4. https://www.chemistryworld.com/news/new-candidate-for-oldest-classroom-periodic-tableemerges-in-russia/3010467.article

5. Georg, C., \& Ost, L. Schlagwortkatalog: Verzeichnis d. Bücher u. Landkt. in sachl. Anordnung. (Cruse, 1889).

6. Gerhardt, C. Preis-Verzeichniss über chemische Apparate und Geräthschaften (Carl Georgi, 1888).

7. St Andrews University Special Collections UYUC634. Arnott apparatus fund 1880-1908.

8. https://www.regionalgeschichte.net/mittelrhein/koblenz/geschichte.html 
9. https://www.regionalgeschichte.net/?id=7687

10. http://www.koblenzer-stadtgruen-friedhoefe.de/foerderprojekt-suedallee.html

11. https://stadtarchivkoblenz.files.wordpress.com/2016/01/stadtchronik_1919-1960.pdf

12. https://www.britannica.com/place/Germany/The-era-of-partition\#ref58214

13. Mendeleev, D. I., Annalen der Chemie und Pharmacie, Supplement 8, 133-229 (1872).

14. Mendeleev, D. I. Zeitschrift für Chemie, 12, 405-406 (1869).

15. Quam, G. N. \& Quam, M. B. J. Chem. Educ. 11, 217-223 (1934).

16. Richards T. W. Am. Chem. J. 20, 543-554 (1898).

17. Bensaude-Vincent, B. Matière à penser: Essais d'histoire et de philosophie de la chimie (Presses universitaires de Paris Ouest, 2012).

18. Lami, E. O. Dictionnaire encyclopédique et biographique de l'industrie et des arts industriels (Librairie des dictionnaires, 1887).

19. http://www.ciaaw.org/beryllium.htm

20. http://www.vanderkrogt.net/elements/element.php?sym=Tm

21. Khvolson O. D. Traité de Physique Suppl. 1 (A. Hermann et fils, 1925).

\section{Acknowledgements}

The authors would like to extend a very special thanks to Jürgen Klug for his detailed comments on the discovery of the Koblenz table and to Alan Aitken, the discoverer of the St Andrews table. We are grateful to Santiago Alvarez and to David Cole-Hamilton for their comments on the early versions of this article.

\section{Figures}




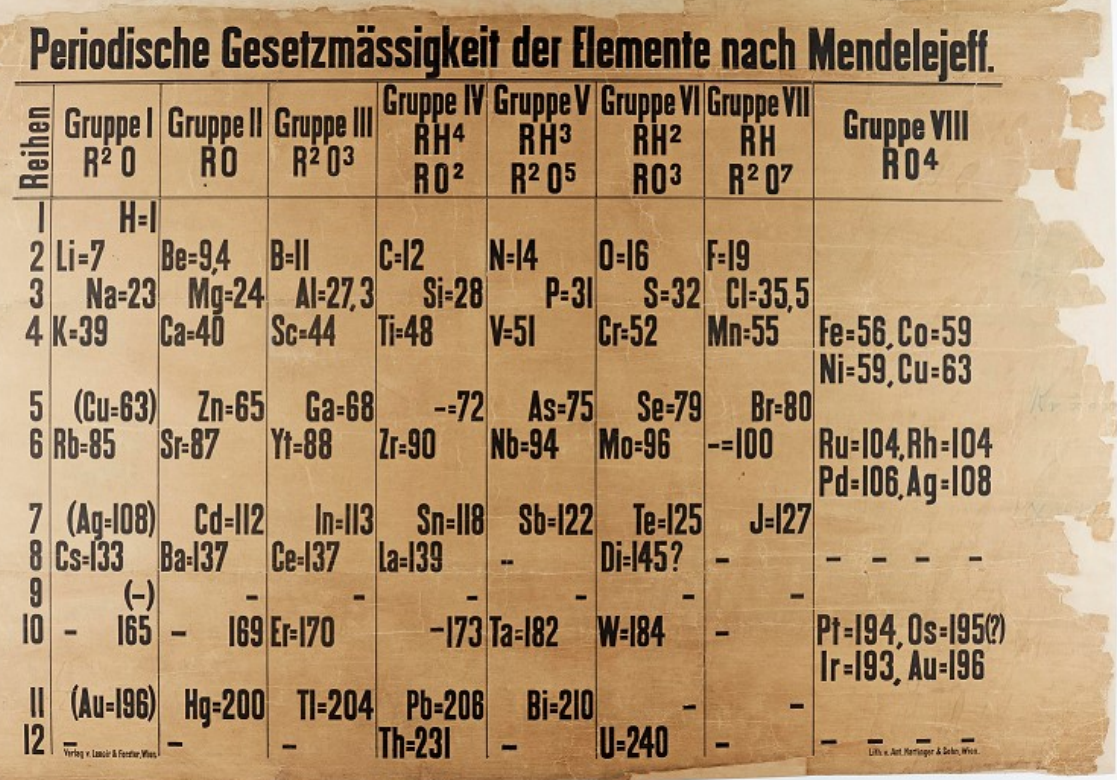

Fig. 1 | The St Andrews periodic table. Courtesy of the University of St Andrews Library: ms39012.

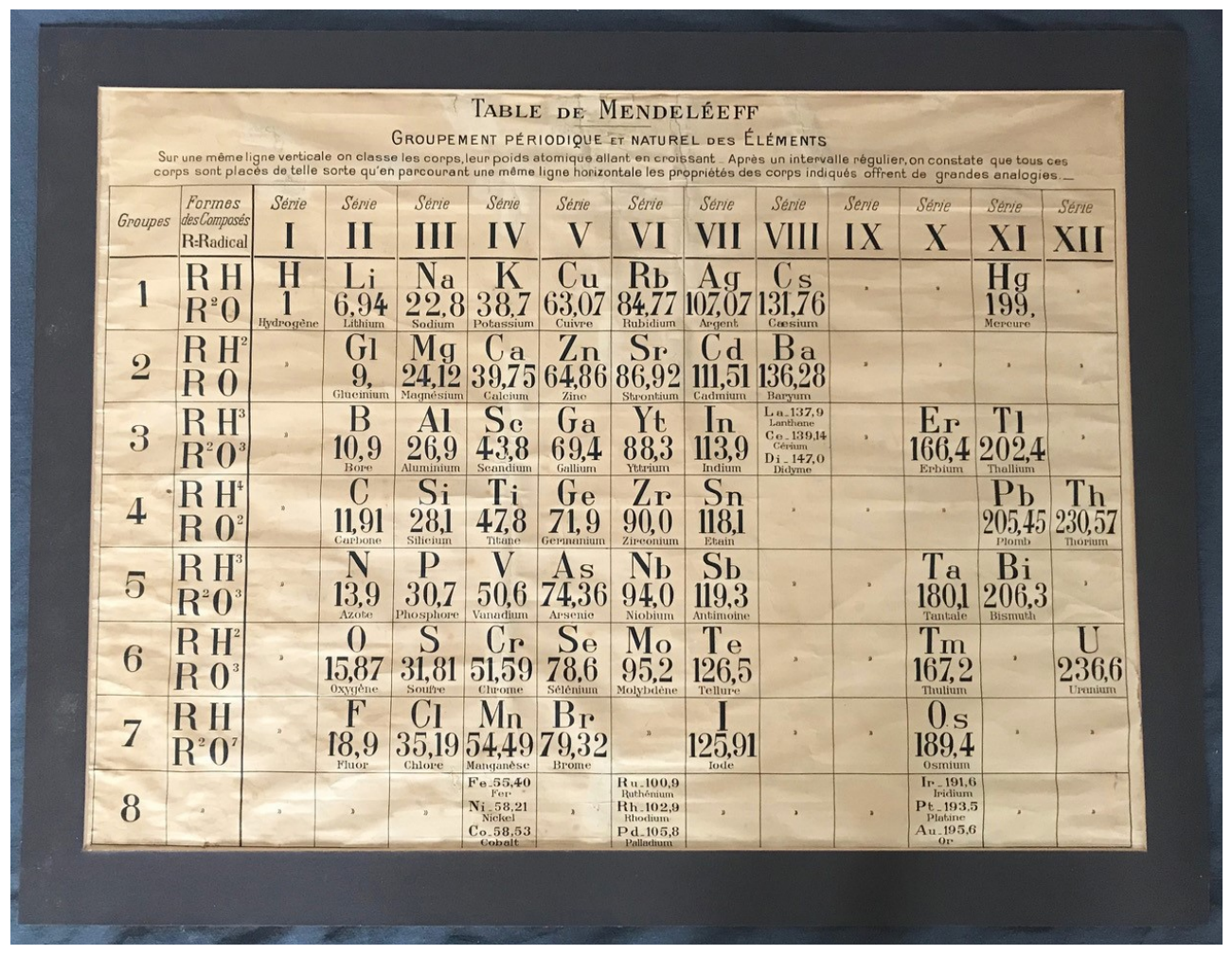

Fig. 2 | The periodic table found in Koblenz. The photograph is of the table in the condition it was found in, prior to any conservation work. Picture courtesy of J. Klug. 